\title{
A study on 'Performance Evaluation of Select Textile Companies An Empirical Analysis'
}

\author{
Varsha Gupta \\ Assistant Professor, School of Management Studies Baddi University of Emerging Sciences and Technology, \\ Baddi, Himachal Pradesh
}

\begin{abstract}
Indian Textile industry has played a pioneered role in growth and upliftment of country. It is the sector that contributes approx 14 per cent to industrial production, 4 per cent to GDP and Approx 13 Percent of total exports of the country. The sector has offered employment to around 45 million people, by acting as one of the biggest employment generator sector. In spite of having such a remarkable records, companies in textile industry are facing many problems like shortage of raw material, obsolete machinery, power shortage, low productivity of labour and competition in foreign market. So the objective of the study is to measure and compare the performance of selected textile companies in India during last five years. The secondary data collected is analyzed using various statistical tools and techniques such as Ratio analysis and one way ANOVA. To measure the financial performance of selected textile companies, in terms of Managerial efficiency, Liquidity, Profitability and Solvency position of the companies, ratio analysis has been used. Further one way ANOVA has been used to identify if there exist a significant difference in the mean and performance of different textile companies. The results showed that there is significance difference in the Return on Capital Employed, Net Profit Margin, Current Ratio, Debt to Equity Ratio, and Fixed Asset turnover ratio of sample Textile companies at $5 \%$ level of significance.
\end{abstract}

Keywords: Compound Annual Growth Rate (CAGR), Liquidity, Profitability, Return on Capital Employed, Textile companies,

\section{Introduction}

India's textiles sector is one of the oldest industries in Indian economy dating back several centuries. Even today, textiles sector is one of the largest contributors to India's exports with approximately 13 per cent of total exports. The textiles industry is also labour intensive and is one of the largest employers. The textile industry employs about 40 million workers and 60 million indirectly. India's overall textile exports during FY 2015-16 stood at US\$ 40 billion.

The textile and apparel industry can be broadly divided into two segments:

- Yarn and fibre (include natural and man-made)

- Processed fabrics (including woolen textiles, silk textiles, jute textiles, cotton textiles and technical textiles), Readymade Garments (RMGs) and apparel

Emergence of Indian Textile Sector has been noticed during year 1854 when the first cotton textile mill was established in 1854 in Mumbai followed by set up of first cotton mill in 1861 in Ahmadabad. The journey continued and the number of Mills increased from 178 in 1901 to 417 in 1945. After partition India received 409 textile Mills out of 423 . With passage of time Technology Upgradation Fund Scheme (TUFS) was set up to provide easy access to capital for technological up gradation in1999 and National Textile Policy (NTP) was announced for the overall development of the textile and apparel industry in 2000. (Scheme for Integrated Textile Park) SITP was set up in 2005 to provide necessary infrastructure to new textile units. Further restructured TUFS was launched attracting a subsidy cap of USD420.65 Million 2014 onwards, Make in India campaign was launched to attract manufacturers and FDI. Under Union Budget 2016-17, Government of India allocated around USD 701.9 million for textile Industry. Major focus of this budget is to attract manufacturers, initiate technology up gradation, and setup integrated textiles parks, etc.

\section{Status Of Production In Textile Sector In India}

- Production of raw cotton in India grew from 28 million bales in FY07 to 38 million bales in FY15 and further increased to 35.2 million bales in FY16 this indicates that the raw cotton production expanded at a CAGR of 2.6 per cent during FY07-16,

- Production stood at 1.34 million tonnes in FY15 that has increased from 1.14 million tonnes in FY 07. During the period of FY07-15, production increased at a CAGR of 2.0 per cent

- Production of yarn grew to 673.60 Lakh Kgs in FY15 from 626.30 Lakh Kgs in FY11, implying a CAGR of 1.8 per cent.

- Export grew to USD41.4 billion in FY15 from USD17.6 billion in FY06, implying a CAGR of 9.97 per cent. The government has extended the duty drawback facility on all textile products and increased the rates in some cases for one year to boost exports in the 


\section{Literature Review}

- As per UN Comtrade data released in June, 2014, 'India was announced as the world's second largest exporter of textiles and clothing in the world and 6th largest exporter of clothing only so total market share of India's textile and garments is $63 \%$ '. India is the 2 nd biggest producer of silk and cotton. India accounts for about 14 per cent of the world's production of textile fibres and yarns (largest producer of jute, second largest producer of silk and cotton; and third largest in cellulosic fibre).

- Ayyappan, S et. al. (2014) in their paper worked on three textile companies and suggested to increase their production to improve their return on capital employed.

- Raichurkar, P \& Ramachandran, M (2015) talked about problems and challenges faced by Indian textile industry. They hold obsolete textile machineries responsible for low productivity. To overcome this problem and to stand in competition, Indian Textile Industry needs high investments. Further Investment in spinning and weaving equipment are increased very rapidly in Countries which is producing and exporting textiles. The Government of India is also devising suitable measures to facilitate that the Textile Industry grows at the rate of $18 \%$ per annum.

- Indhumathi, C and Palanivelu, P. (2013) stated in their study the correlation coefficient matrices of the selected variables with the dependent variable, i.e., return on total assets of selected companies' state that almost all the companies creditors turnover ratio, inventory turnover ratio and fixed asset turnover ratio were positively correlated with profitability of the company. They further concluded that there was a close relationship between the financial performances of the selected textiles companies in India and the proportion of changes in return on total assets.

- Yimin Zhang and Tianmu Wang (2010) have considered the cost structure, profitability and productivity of the Chinese textile industry and estimated the impacts of RMB appreciation on this industry for 1999-2006. It was found that the industry had suffered from very low profit margins and returns on capital. Because the input prices have been increasing, particularly since 2001, generating profits had become more difficult task for the industry.

- Nevertheless, the industry achieved substantial productivity growth during the period examined. Although at an inadequate level, the profitability of the industry did show some signs of improvement. As long as this trend continued, the industry could have obtained a decent level of profitability. Since 2005, the industry has faced a new challenge; the appreciation of the RMB. Based on 2006 data, it estimated the maximum rate of RMB appreciation that the industry would be able to sustain to be approximately 5 per cent a year

Most of the studies have talked about Indian textile industry, their growth an contributions, problems and challenges faced in totality but we have very less studies available focusing on individual textile companies and their financial performance. So the paper focuses on analyzing the financial performance of selected Textiles companies which has been termed as topkey players in this segment in the IBEF report Nov, 2016.

\section{Objectives}

- To measure the financial performance of selected textile companies during last five years.

- To make a comparative analysis of liquidity, solvency, profitability and managerial efficiency position of key textile players in India.

\section{Methodology}

Secondary data has been collected from various sources like Research papers, reports published by IBEF and from Annual Reports of TechSci Research. Following Textile companies has been selected for study

- Welspun India Ltd: Home textiles, bathrobes, terry towels

- Vardhman Group: Yarn, fabric, sewing threads, acrylic fiber

- Alok Industries Ltd: Home textiles, woven and knitted apparel fabric, garments and polyester yarn

- Raymond Ltd: Worsted suiting, tailored clothing, denim, shirting, woolen outerwear

- Arvind Mills Ltd: Spinning, weaving, processing and garment production (denims, shirting, khakis and knitwear)

- Bombay Dyeing \& Manufacturing Company Ltd: Bed linen, towels, furnishings, fabric for suits, shirts, dresses and saris in cotton and polyester blends

- Garden Silk Mills Ltd Dyed and printed fabric

To measure the financial performance of selected textile companies, in terms of Managerial efficiency, Liquidity, Profitability and Solvency position of the companies, ratio analysis has been used. Further one way ANOVA has been used to identify if there exist a significant difference in the mean and performance of different textile companies.

Analysis: The analysis part is carried out with the help of the following variables

- Profitability position: Return on Capital Employed and Net profit Margin Ratio

- Solvency Position: Debt to Equity Ratio

- Liquidity position: Current Ratio 
- Managerial Efficiency ratio: Fixed Assets Turnover Ratio

Table-1 Return on Capital Employed (\%)

\begin{tabular}{|l|l|l|l|l|l|l|l|}
\hline & $\begin{array}{l}\text { Vardhman } \\
\text { Textile }\end{array}$ & $\begin{array}{l}\text { Arvind Textile } \\
\text { Mills }\end{array}$ & $\begin{array}{l}\text { Raymond } \\
\text { Textile Mills }\end{array}$ & $\begin{array}{l}\text { Garden Silk } \\
\text { Textile Mills }\end{array}$ & $\begin{array}{l}\text { Bombay } \\
\text { Dyeing } \\
\text { Manufacturing }\end{array}$ & $\begin{array}{l}\text { Alok } \\
\text { Industries Ltd }\end{array}$ & $\begin{array}{l}\text { Welspun } \\
\text { India Ltd }\end{array}$ \\
\hline Mar '16 & 16.97 & 14.2 & 10.93 & 3.84 & 8.16 & -15.27 & 24.92 \\
\hline Mar '15 & 12.54 & 16.33 & 11.5 & 3.32 & 14.47 & 20.38 & 25.11 \\
\hline Mar '14 & 18.38 & 15.64 & 9.31 & -1.69 & 14.59 & 21.92 & 5.89 \\
\hline Mar '13 & 12.53 & 13.29 & 7.32 & -0.11 & 19.08 & 21.92 & 13.75 \\
\hline Mar '12 & 6.61 & 15.19 & 8.97 & 2.04 & 20.82 & 12.91 & 15.5 \\
\hline Mean & $\mathbf{1 3 . 4 0 6}$ & $\mathbf{1 4 . 9 3}$ & $\mathbf{9 . 6 0 6}$ & $\mathbf{1 . 4 8}$ & $\mathbf{1 5 . 4 2 4}$ & $\mathbf{1 2 . 3 7 2}$ & $\mathbf{1 7 . 0 3 4}$ \\
\hline SD & $\mathbf{4 . 6 1 3 7 2 2}$ & $\mathbf{1 . 1 9 9 3 9 6}$ & $\mathbf{1 . 6 6 2 6 8 8}$ & $\mathbf{2 . 3 3 6 9 7 5}$ & $\mathbf{4 . 9 2 0 7 3 5}$ & $\mathbf{1 5 . 8 9 6 7 5}$ & $\mathbf{8 . 1 3 5 3 7 5}$ \\
\hline
\end{tabular}

The table-1 indicates that Welspun India, Bombay Dyeing and Manufacturing, Arvind Textile, Vardhman Textile and Alok Industries are earning over average industry return i.e. 12.036. While that of Raymond textile and Garden Silk Textile is below industry average return. Moreover ROCE of Vardhamn, Raymond, Garden Silk and Welspun India has increased since 2012 while the return of Arvind Textile and Bombay Dyeing has fallen down. Alok Industries ltd has depicted negative return in FY 2016.

Table-2 Net Profit Margin (\%)

\begin{tabular}{|l|l|l|l|l|l|l|l|}
\hline & $\begin{array}{l}\text { Vardhman } \\
\text { Textile }\end{array}$ & $\begin{array}{l}\text { Arvind Textile } \\
\text { Mills }\end{array}$ & $\begin{array}{l}\text { Raymond } \\
\text { Textile Mills }\end{array}$ & $\begin{array}{l}\text { Garden Silk } \\
\text { Textile Mills }\end{array}$ & $\begin{array}{l}\text { Bombay } \\
\text { Dyeing \& \& } \\
\text { Manufacturing }\end{array}$ & $\begin{array}{l}\text { Alok } \text { Industries Ltd } \\
\text { India Ltd }\end{array}$ \\
\hline Mar'16 & 11.68 & 5.89 & 2.93 & -5.91 & -4.62 & -31.67 & 12.36 \\
\hline Mar'15 & 6.25 & 7.22 & 3.78 & -5.4 & 1.03 & 1.57 & 11.57 \\
\hline Mar'14 & 12.6 & 7.56 & 4.03 & -4.71 & 0.91 & 4.6 & 0.84 \\
\hline Mar'13 & 7.78 & 6.91 & -2.35 & -2.72 & 3.24 & 4.61 & 5.63 \\
\hline Mar'12 & 2.79 & 12.42 & 2.99 & -2.24 & 2.66 & 4.27 & 4.52 \\
\hline Mean & $\mathbf{8 . 2 2}$ & $\mathbf{8}$ & $\mathbf{2 . 2 7 6}$ & $\mathbf{- 4 . 1 9 6}$ & $\mathbf{0 . 6 4 4}$ & $\mathbf{- 3 . 3 2 4}$ & $\mathbf{6 . 9 8 4}$ \\
\hline SD & $\mathbf{4 . 0 2 2 2 9}$ & $\mathbf{2 . 5 4 8 4 6}$ & $\mathbf{2 . 6 3 0 4}$ & $\mathbf{1 . 6 3 2 1 9}$ & $\mathbf{3 . 1 1 1 7 9}$ & $\mathbf{1 5 . 8 9 7}$ & $\mathbf{4 . 8 8 8 4 1}$ \\
\hline
\end{tabular}

Table 2 indicate that only Vardhman, Arvind Textile and Welspun has average net profit margin above industry return i.e.2.66, while rest of the companies has net profit margin below the average industry net profit margin and even Garden Silk and Alok Industries has negative profit margins. Comparing with previous year's performance, only Vardhman and Welspun India ltd has shown positive and growing trend since year 2012 to year 2016.

Table-3 Current Ratio

\begin{tabular}{|l|l|l|l|l|l|l|l|}
\hline & $\begin{array}{l}\text { Vardhman } \\
\text { Textile }\end{array}$ & $\begin{array}{l}\text { Arvind } \\
\text { Textile Mills }\end{array}$ & $\begin{array}{l}\text { Raymond } \\
\text { Textile Mills }\end{array}$ & $\begin{array}{l}\text { Garden Silk } \\
\text { Textile Mills }\end{array}$ & $\begin{array}{l}\text { Bombay } \\
\text { Dyeing \& } \\
\text { Manufacturing }\end{array}$ & $\begin{array}{l}\text { Alok Industries Ltd } \\
\text { India Ltd }\end{array}$ \\
\hline Mar '16 & 1.08 & 0.81 & 1.1 & 0.63 & 1.47 & 0.69 & 0.8 \\
\hline Mar '15 & 1.3 & 0.83 & 1.2 & 0.85 & 1.6 & 0.91 & 0.77 \\
\hline Mar '14 & 1.14 & 0.85 & 1.18 & 1.13 & 1.22 & 0.98 & 0.63 \\
\hline Mar '13 & 1.16 & 0.75 & 0.83 & 1.25 & 1.42 & 0.98 & 0.65 \\
\hline Mar '12 & 1.3 & 0.67 & 0.95 & 0.77 & 1.59 & 0.77 & 0.75 \\
\hline Mean & $\mathbf{1 . 1 9 6}$ & $\mathbf{0 . 7 8 2}$ & $\mathbf{1 . 0 5 2}$ & $\mathbf{0 . 9 2 6}$ & $\mathbf{1 . 4 6}$ & $\mathbf{0 . 8 6 6}$ & $\mathbf{0 . 7 2}$ \\
\hline SD & $\mathbf{0 . 0 9 9 4}$ & $\mathbf{0 . 0 7 2 9 4}$ & $\mathbf{0 . 1 5 8 3 4}$ & $\mathbf{0 . 2 5 7 0 6}$ & $\mathbf{0 . 1 5 4 7 6}$ & $\mathbf{0 . 1 3 0 5}$ & $\mathbf{0 . 0 7 5 5}$ \\
\hline
\end{tabular}

Table 3 Depict that none of the companies has been able to maintain ideal current asset ratio i.e. 2:1. Bombay dyeing and manufacturing, Vardhman Textile and Raymond has been in position to maintain their current assets above their current liabilities but in rest of the companies, current liabilities are more than current assets creating liquidity crunches for them.

Table-4 Debt Equity Ratio

\begin{tabular}{|l|l|l|l|l|l|l|l|}
\hline & $\begin{array}{l}\text { Vardhman } \\
\text { Textile }\end{array}$ & $\begin{array}{l}\text { Arvind Textile } \\
\text { Mills }\end{array}$ & $\begin{array}{l}\text { Raymond } \\
\text { Textile Mills }\end{array}$ & $\begin{array}{l}\text { Garden Silk } \\
\text { Textile Mills }\end{array}$ & $\begin{array}{l}\text { Bombay } \\
\text { Dyeing \& } \\
\text { Manufacturing }\end{array}$ & $\begin{array}{l}\text { Alok Industries Ltd } \\
\text { India Ltd }\end{array}$ \\
\hline Mar '16 & 0.53 & 0.97 & 0.95 & -- & 5.4 & 11.29 & 1.14 \\
\hline Mar '15 & 0.58 & 0.97 & 0.93 & 9.64 & 2.82 & 2.45 & 1.41 \\
\hline Mar '14 & 0.97 & 0.95 & 1.13 & 4.85 & 2.27 & 2.7 & 2.05 \\
\hline Mar '13 & 1.2 & 0.97 & 0.98 & 3.3 & 2.06 & 2.7 & 1.51 \\
\hline Mar '12 & 1.22 & 0.93 & 0.91 & 2.57 & 1.96 & 3.05 & 1.57 \\
\hline Mean & $\mathbf{0 . 9}$ & $\mathbf{0 . 9 5 8}$ & $\mathbf{0 . 9 8}$ & $\mathbf{4 . 1 9 8}$ & $\mathbf{2 . 9 0 2}$ & $\mathbf{4 . 4 3 8}$ & $\mathbf{1 . 5 3 6}$ \\
\hline SD & $\mathbf{0 . 3 3 0 3 8}$ & $\mathbf{0 . 0 1 7 8 9}$ & $\mathbf{0 . 0 8 7 7 5}$ & $\mathbf{3 . 3 9 9 5 5}$ & $\mathbf{1 . 4 3 5 4 9}$ & $\mathbf{3 . 8 3 6 3 4}$ & $\mathbf{0 . 3 3 1 1 8}$ \\
\hline
\end{tabular}


Table 4 indicates that Garden silk, Alok industries and Bombay Dyeing has leveraged their portfolio by including more of debts along with equities. Proportion of debts varies from $60 \%$ to $85 \%$ in their portfolio. While the same for Vardhman textile, Arvind textile and Raymond Textile is below 50\% indicating less involvement of debts than equity.

Table-5 Fixed Assets Turnover Ratio

\begin{tabular}{|l|l|l|l|l|l|l|l|}
\hline & $\begin{array}{l}\text { Vardhman } \\
\text { Textile }\end{array}$ & $\begin{array}{l}\text { Arvind Textile } \\
\text { Mills }\end{array}$ & $\begin{array}{l}\text { Raymons } \\
\text { Textile Mills }\end{array}$ & $\begin{array}{l}\text { Garden Silk } \\
\text { Textile Mills }\end{array}$ & $\begin{array}{l}\text { Bombay } \\
\text { Dyeing \& } \\
\text { Manufacturing }\end{array}$ & $\begin{array}{l}\text { Alok Industries Ltd } \\
\text { India Ltd }\end{array}$ \\
\hline Mar '16 & 1 & 1.18 & 1.51 & 1.12 & 1.91 & 0.87 & 1.06 \\
\hline Mar '15 & 1.09 & 1.2 & 1.46 & 1.26 & 1.77 & 1.65 & 1.23 \\
\hline Mar '14 & 1.03 & 1.18 & 1.23 & 1.46 & 2.04 & 1.55 & 1.3 \\
\hline Mar '13 & 0.97 & 1 & 1.1 & 1.82 & 1.78 & 1.55 & 1.23 \\
\hline Mar '12 & 0.99 & 0.99 & 1.04 & 1.75 & 1.76 & 0.82 & 1.13 \\
\hline Mean & $\mathbf{1 . 0 1 6}$ & $\mathbf{1 . 1 1}$ & $\mathbf{1 . 2 6 8}$ & $\mathbf{1 . 4 8 2}$ & $\mathbf{1 . 8 5 2}$ & $\mathbf{1 . 2 8 8}$ & $\mathbf{1 . 1 9}$ \\
\hline SD & $\mathbf{0 . 0 4 6 6 9}$ & $\mathbf{0 . 1 0 5 3 6}$ & $\mathbf{0 . 2 1 0 4}$ & $\mathbf{0 . 3 0 2 8 5}$ & $\mathbf{0 . 1 2 1 5 3}$ & $\mathbf{0 . 4 0 6 8 4}$ & $\mathbf{0 . 0 9 4 6}$ \\
\hline
\end{tabular}

The above table states that only Garden Silk (1.48) and Bombay Dyeing (1.85) have been able to maintain their fixed asset turnover ratio above industry average fixed asset turnover ratio i.e. 1.31 indicating good managerial efficiency position.

\section{Comparative analysis of the performance of selected companies}

Ho: There is no significance difference among the mean return on capital employed, Net Profit Margin, Current Ratio, Debt to Equity Ratio, and Fixed Asset turnover ratio pertaining to Vardhman Textile, Arvind Textile Mills, Raymond Textile Mills; Garden Silk Textile Mills, Bombay Dyeing \& Manufacturing, Alok Industries Ltd and Welspun India Ltd.

\begin{tabular}{|c|c|c|c|c|c|c|}
\hline \multicolumn{7}{|l|}{ One Way-ANOVA } \\
\hline & & Sum of Squares & $\mathrm{df}$ & Mean Square & $\mathrm{F}$ & Sig. \\
\hline \multirow{3}{*}{$\begin{array}{ll}\text { Return on } & \text { Capital } \\
\text { Employed Ratio } & \end{array}$} & Between Groups & 820.788 & 6 & 136.798 & 2.560 & .042 \\
\hline & Within Groups & 1496.222 & 28 & 53.436 & & \\
\hline & Total & 2317.010 & 34 & & & \\
\hline \multirow[t]{3}{*}{ Net Profit Margin } & Between Groups & 825.754 & 6 & 137.626 & 3.024 & .021 \\
\hline & Within Groups & 1274.199 & 28 & 45.507 & & \\
\hline & Total & 2099.953 & 34 & & & \\
\hline \multirow[t]{3}{*}{ Current Ratio } & Between Groups & 2.010 & 6 & .335 & 15.327 & .000 \\
\hline & Within Groups & .612 & 28 & .022 & & \\
\hline & Total & 2.622 & 34 & & & \\
\hline \multirow[t]{3}{*}{ Debt to Equity Ratio } & Between Groups & 69.998 & 6 & 11.666 & 8.053 & .000 \\
\hline & Within Groups & 39.117 & 27 & 1.449 & & \\
\hline & Total & 109.114 & 33 & & & \\
\hline \multirow{3}{*}{$\begin{array}{l}\text { Fixed } \\
\text { Ratio }\end{array}$} & Between Groups & 2.331 & 6 & .389 & 8.035 & .000 \\
\hline & Within Groups & 1.354 & 28 & .048 & & \\
\hline & Total & 3.685 & 34 & & & \\
\hline
\end{tabular}

\section{Inference}

- Return on Capital Employed Ratio: As p value $<0.05$ (0.042), this shows that there is a significant difference between return on capital employed for selected companies.

- Net Profit Margin: p value <0.05 (0.021), so there is significant difference.

- In Current Ratio, Debt to Equity Ratio and Fixed Asset Turnover Ratio, p value is 0.000 which shows a significant difference in values of all companies.

Further as the calculated value of $\mathrm{F}$ varies in between 2.56 to 15.327 for groups which is greater than table value of F crit $=2.45(6,28)$, there is significance difference in the Return on Capital Employed, Net Profit Margin, Current Ratio, Debt to Equity Ratio, and Fixed Asset turnover ratio of sample Textile companies at 5\% level of significance, thereby rejecting the null hypothesis

\section{Conclusion}

The study concludes that there is significant difference in the performance of all the selected companies in textile industry in terms of their liquidity, solvency, profitability and managerial efficiency position. Welspun India Ltd has been leading all the textile companies in terms of profitability followed by Bombay dyeing and Manufacturing, Arvind Textile and Vardhman Textile while Only Bombay dyeing and Vardhman Textile have maintained comparative better liquidity position by keeping current assets level above current liabilities. Garden Silk and Alok Industries are highly leveraged firms indicating less profits and high risk while Bombay dyeing and manufacturing has debt proportion equalant to industry's average debt equity proportion. Considering 
managerial efficiency, only Garden Silk (1.48) and Bombay Dyeing (1.85) have been able to maintain their fixed asset turnover ratio above industry average fixed asset turnover ratio i.e. 1.31 indicating good managerial efficiency position.

\section{References}

[1]. Ayyappan, S et. al. (2014). Financial Performance Analysis of Selected Textile Industries in India. International Journal of Engineering and Management Research. Volume-4, Issue-3, June-2014, ISSN No.: 2250-0758.

[2]. Indhumathi, C and Palanivelu, P. (2013). A Study on Financial Performance of Selected Textile Companies in India. Global Journal for Research Analysis, Volume : 2, Issue : 7,| July 2013, ISSN No $2277-8160$.

[3]. Raichurkar, P \& Ramachandran, M (2015), Recent Trends and Developments in Textile Industry in India, in International Journal on Textile Engineering and Processes,ISSN: 2395-3578Vol 1, Issue 4,October 2015.

[4]. Report on Textile and Apparel by India Brand Equity Foundation, IBEF in November 2016.

[5]. https://www.researchgate.net/publication/284027876_Recent_Trends_and_Developments_in_Textile_Industry_in_India [accessed Dec 19, 2016].

[6]. http://www.moneycontrol.com/stocks/company_info/print_main.php www.ibef.org 